\title{
SHORT-TERM CREEP OF P91 HEAT-RESISTANT STEELS AT LOW STRESSES AND AN INSTANTANEOUS-STRESS-CHANGE TESTING
}

\author{
KRATKOTRAJNO LEZENJE TOPLOTNO ODPORNEGA JEKLA P91 \\ PRI NIZKIH NAPETOSTIH IN NENADNI MENJAVI NAPETOSTI \\ OBREMENJEVANJA
}

\author{
Jiang Zhe, Shen Junjie, Zhao Pengshuo \\ Tianjin University of Technology, Tianjin Key Laboratory for Advanced Mechatronic System Design and Intelligent Control, National \\ Demonstration Center for Experimental Mechanical and Electrical Engineering Education, 391 Binshui Road, Xiqing District, Tianjin, China \\ sjj1982428@sina.com, j211209977@live.com
}

Prejem rokopisa - received: 2016-1'-20; sprejem za objavo - accepted for publication: 2017-03-21

doi:10.17222/mit.2016.305

For the short-term creep behavior to be evaluated and the creep mechanism of P91 heat-resistant steels at low stresses and high temperatures to be clarified, stress-change testing was conducted with a "helicoidal-spring creep test" demonstrating a high strain resolution. The creep deformation consists of the primary creep stage, whereas no secondary creep stage was observed. Blackburn's law was suggested to be the best choice for a short-term-creep-behavior description because it provides a good representation of an experimental creep curve. An anelastic backflow at a low stress was confirmed, following a high reduction in the stress. The absolute value of the instantaneous strain for a load increase was equal to the value for a load decrease and the creep of the P91 steels at low stresses might have been controlled by the viscous glide of dislocations.

Keywords: P91 heat-resistant steel, creep, anelastic, stress change

Da bi bilo moč oceniti kratkotrajno lezenje in njegov mehanizem toplotno obstojnega jekla P91 pri nizkih napetostih in visokih temperaturah, so bili izvedeni preizkusi spremembe napetosti z uporabo t.i. testa spiralne vzmeti, ki omogoča veliko ločljivost deformacije. Deformacija lezenja sestoji iz primarne in sekundarne faze lezenja, vendar sekundarne faze niso analizirali oz. opazovali. Blackburnov zakon je najbolj uporaben zakon za opis obnašanja jekla med kratkotrajnim lezenjem, ker se $z$ njim najbolj približamo rezultatom, dobljenim z eksperimenti. Neelastični povratni tok pri nizki napetosti je bil potrjen z večjim zmanjšanjem napetosti. Zaradi absolutne vrednosti trenutne deformacije za dano obremenitev je bil narastek deformacije enak zmanjšanju obremenitve, medtem ko je lezenje pri nizkih napetostih jekla P91 kontrolirano z viskoznim drsenjem dislokacij.

Ključne besede: P91 jeklo za delo v vročem, lezenje, neelastičnost, sprememba napetosti

\section{INTRODUCTION}

The P91 ferritic heat-resistant steel is utilized for the material production of thermal-power-plant components, which are exposed to elevated temperatures for extensive periods. This requires that the P91 structural materials resist creep deformation at both high temperatures and low stresses. The creep strength obtained with the extrapolation method based on the data of the creep deformation at a high stress is higher than the true creep strength under these conditions (at low stresses). ${ }^{1,2}$ The creepstrength degradation is not only based on the microstructural degradation ${ }^{3-6}$, but it is also related to the change in the creep mechanism..$^{7-9}$ The creep-mechanism clarification has to depend on the instantaneous creep behavior because the long-term creep is associated with the microstructural degradation. The stress-change test constitutes an effective method for a creep-deformation-mechanism clarification based on the instantaneous-strain and creep-rate-variation evaluation at the stress changes during the creep testing. ${ }^{10-12}$
At a high strain rate (a high stress) and a high temperature, a sudden-stress-change experiment has been widely utilized for pure metals and solution-strengthened alloys. ${ }^{10-12}$ In contrast, at a low strain rate $\varepsilon$, especially the ultra-low $\varepsilon$, lower than $10^{-10} \mathrm{~s}^{-1}$, it is usually impossible for a conventional tension-creep technique to distinguish the instantaneous plastic strain from the total strain under a sudden stress change, due to the unsatisfactory strain resolution, existing between $10^{-6}$ and $10^{-5}$. As an additional creep technique, the helicoidal-spring creep test based on torsion deformation provides a significantly high strain resolution, even up to $10^{-9} .{ }^{13}$ Due to this high strain resolution, it is possible for very low instantaneous strains to be measured during a sudden stress change. ${ }^{14}$

In the present study, the instantaneous creep of the P91 ferritic heat-resistant steels was studied during sudden-stress-change experiments using the helicoidalspring-specimen technique for the creep mechanism under both a low stress and a high temperature. 
J. ZHE et al.: SHORT-TERM CREEP OF P91 HEAT-RESISTANT STEELS AT LOW STRESSES ...

Table 1: Chemical components of P91

\begin{tabular}{|c|c|c|c|c|c|c|c|c|c|c|c|c|c|}
\hline Element & $\mathrm{Cr}$ & $\mathrm{Mo}$ & $\mathrm{Si}$ & $\mathrm{V}$ & $\mathrm{C}$ & $\mathrm{Nb}$ & $\mathrm{Cu}$ & $\mathrm{N}$ & $\mathrm{P}$ & $\mathrm{Ni}$ & $\mathrm{Ti}$ & $\mathrm{Al}$ & $\mathrm{S}$ \\
\hline Content $(\%)$ & 9.50 & 0.91 & 0.60 & 0.20 & 0.10 & 0.10 & 0.07 & 0.04 & 0.02 & 0.02 & 0.01 & 0.01 & 0.01 \\
\hline
\end{tabular}

\section{EXPERIMENTAL PART}

\subsection{Materials}

The P91 heat-resistant steel was utilized in this experiment. The chemical components are presented in Table $\mathbf{1}$.

\subsection{Specimen processing}

The steel was processed into helicoidal-spring specimens using the method of high-speed wire-electrode cutting machining; the outer and inner diameters of the specimens were $12 \mathrm{~mm}$ and $8 \mathrm{~mm}$, respectively. The cross-section of the helicoidal-spring specimens was a rectangle. The side length of the rectangle was $2 \mathrm{~mm}$, as presented in Figure 1.

The helicoidal-spring specimens were annealed at $1313 \mathrm{~K}$ for $60 \mathrm{~min}$ and consequently tempered at $1033 \mathrm{~K}$ for $60 \mathrm{~min}$.

\subsection{Test methods}

Figure 2 presents the experimental apparatus, which includes an electric furnace with three adjacent heaters, a high-precision optical micrometer, a load, a weight and a system for receiving and processing information. By measuring the helicoidal-spring-specimen pitch change, the creep curves could be obtained. The test-apparatus details were previously reported..$^{14}$

During the testing, the number of weights was increased or decreased for the instantaneous stress change

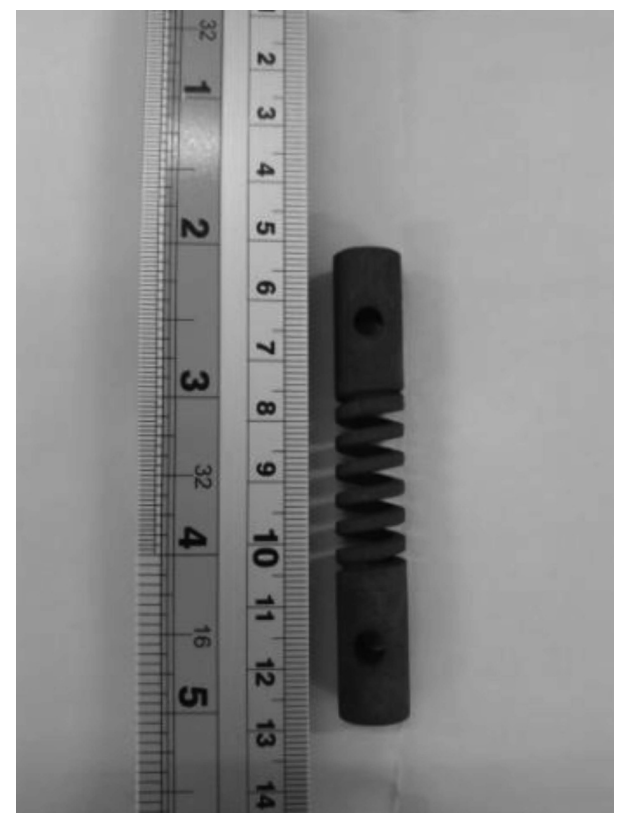

Figure 1: Helicoidal-spring specimen for the stress-change testing to be observed. The weight was suspended under a load with a flammable thread. In order for a load to be increased, the load was hooked quickly. For a load to be decreased, the flammable thread was burned.

The test was performed at a temperature of $923 \mathrm{~K}$ and a slight oscillation. The specimen was loaded subsequently for five days when the strain rate was down to $10^{-9}-10^{-8} \mathrm{~s}^{-1}$. Also, the stress consequently increased or decreased at various applied levels and the instantaneous strain was measured. The following equations ${ }^{15,16}$ were utilized for calculating the mean surface shear stress, $\tau$, and the surface shear strain, $\gamma$, with the assumption of the pure torsion of the helicoidal-spring specimen:

$$
\begin{gathered}
\tau=\frac{P D}{2 a^{2} b} \\
\gamma=\frac{2 a}{\pi D^{2}} \Delta \delta
\end{gathered}
$$

where $P$ is the average load, $D$ is the coil diameter $(12 \mathrm{~mm})$ and $\Delta \delta$ is the displacement of the mean coil-pitch spacing. In this study, the torsion was the dominant component of deformation, because $D$ was quite higher than $d(D / d>12)^{17}$ and the value of $\delta$ was between $2 \mathrm{~mm}$ and $4 \mathrm{~mm} .{ }^{18}$ Since the stress and strain in the helicoidal spring had essentially shear components, the former could be transformed into the equivalent tensile quantities with the von Mises equations for the tensile stress $\sigma=\sqrt{3} \tau$ and the tensile strain $\varepsilon=\gamma / \sqrt{3}$.

\section{RESULTS AND DISCUSSION}

Figure 3 demonstrates the creep curves obtained at $923 \mathrm{~K}$ and at various stresses: $(34.85,27.75$ and 19.35) MPa.

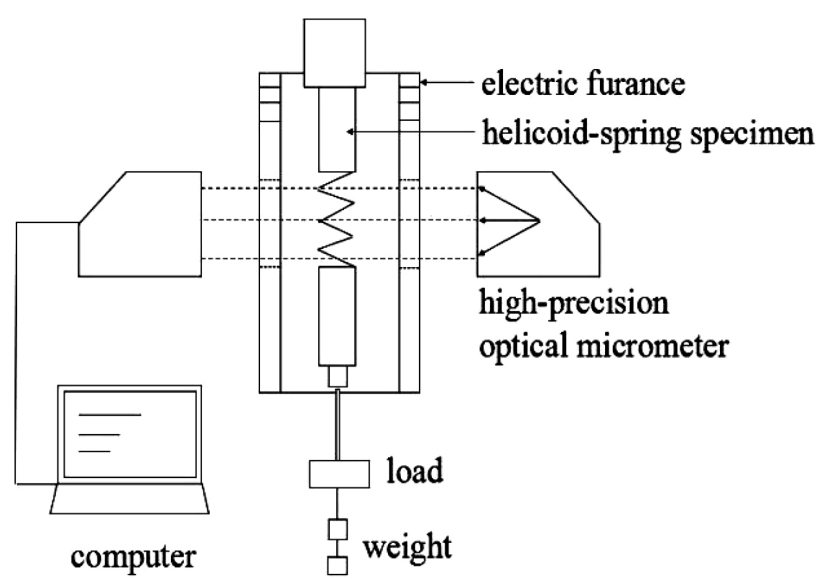

Figure 2: Experimental apparatus including electric furnace, highprecision optical micrometer, load, weight and information-receiving and processing system 


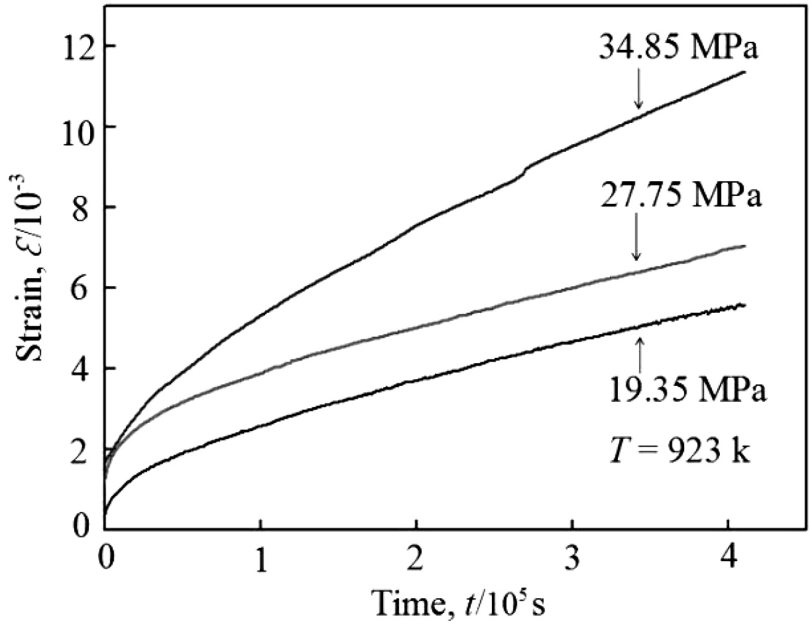

Figure 3: Strain/time creep curves for P91 at $923 \mathrm{~K}$ and various stresses

The creep rate which corresponded to the slope of the curves decreased as the duration increased.

Figure 4 presents the strain rate on a logarithmic plot versus the strain at $923 \mathrm{~K}$ and various stresses. The creep deformation of the P91 steels consisted of the primary creep stages where the creep rate decreased along with the strain and no apparent secondary (steady-state) creep stage was observed where the creep rate would not change along with the strain.

The constitutive creep equations expressing the primary stages should be utilized in the experimental creep-curve analysis. The following constitutive creep equations were utilized, being widely accepted as the basic creep equations. ${ }^{19,20}$

Power law:

$\varepsilon=\varepsilon_{0}+a t^{\mathrm{b}}$

Exponential law:

$\varepsilon=\varepsilon_{0}+a[1-\exp (-b t)]$

Logarithmic law:

$\varepsilon=\varepsilon_{0}+a \ln (1+b t)$

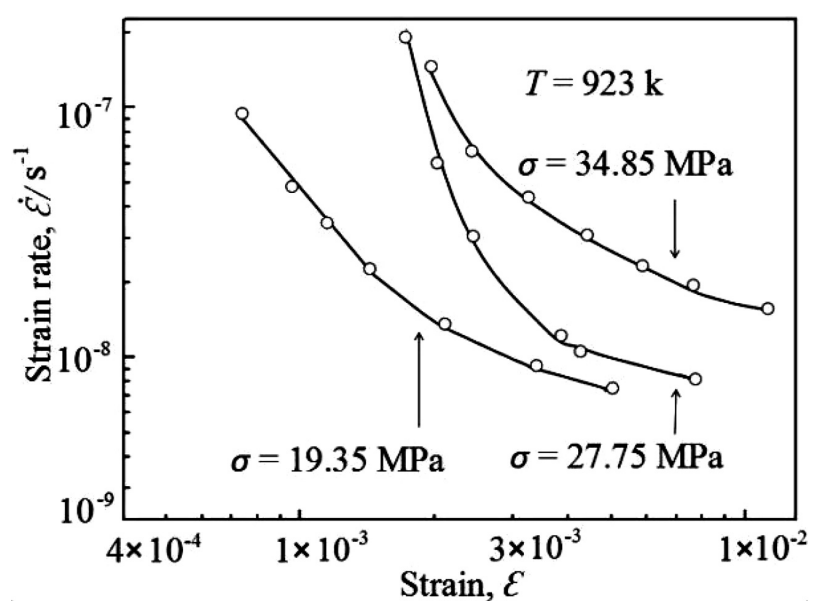

Figure 4: Strain rate/strain creep curves at $923 \mathrm{~K}$ and various stresses
Blackburn's law:

$\varepsilon=\varepsilon_{0}+\mathrm{ac}[1-\exp (-b t)]+\mathrm{c}[1-\exp (-d t)]$

where $\varepsilon$ is the strain, $\varepsilon_{0}$ is the instantaneous strain on dead weight, $t$ is the elapsed time and $a, b, c$ and $d$ are the parameters characterizing the primary creep region. The $a, b, c$ and $d$ values were called the "scaling factors". ${ }^{21}$

Figure 5 presents representative results of a regression analysis, for the creep at $923 \mathrm{~K}$ and $27.75 \mathrm{MPa}$. The exponential-law and power-law equations did not reproduce the experimental data. Compared to the logarithmic-law equation, the Blackburn equation provided a better representation of the experimental creep curve. Therefore, the short-term creep for the P91 heat-resistant steels at low stresses could be described with the Blackburn equation.

In order for the creep mechanism of the P91 steels at low stresses to be studied, the instantaneous creep behavior was investigated. The specimens were loaded for $4.3 \times 10^{5} \mathrm{~s}$ until the strain reached $6 \times 10^{-3}$. In this case, the dislocations could be expected to move. The stress increased or decreased at various levels that were consequently applied and the instantaneous strain was measured.

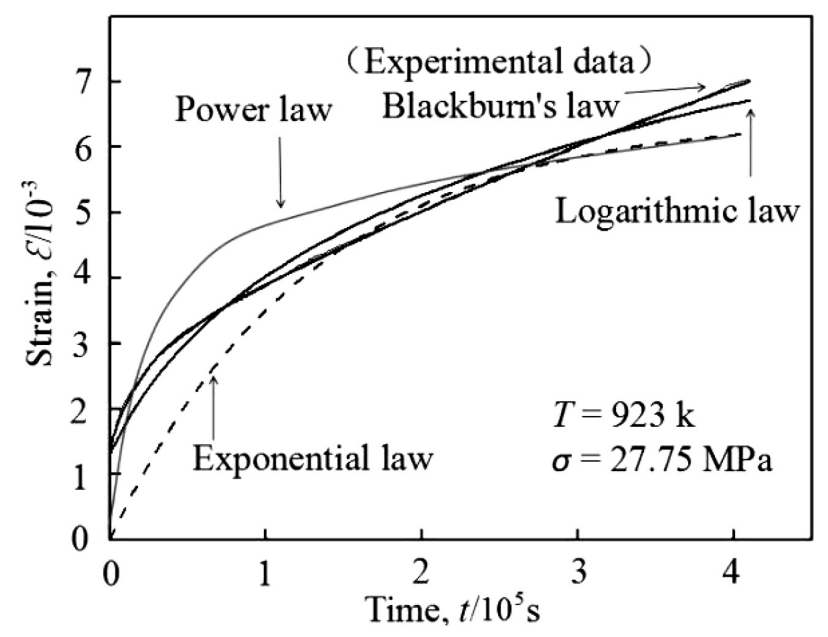

Figure 5: Comparison of experimental data and predicted curves of strain versus time at $923 \mathrm{~K}$ and $27.75 \mathrm{MPa}$

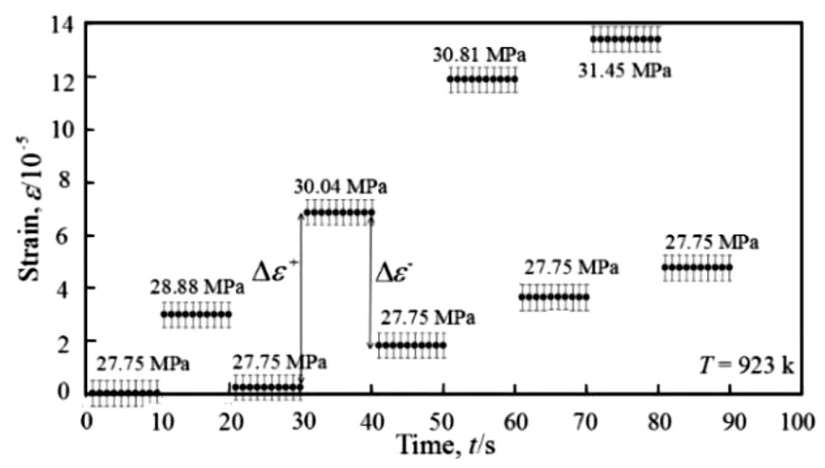

Figure 6: Example of instantaneous elongation and contraction upon low stress changes at a high temperature 


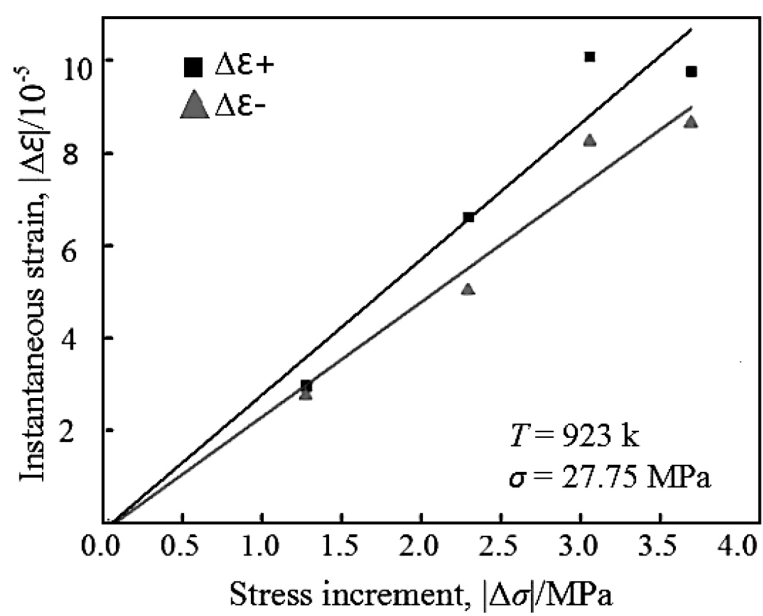

Figure 7: Instantaneous strain at a high temperature $(T=923 \mathrm{~K})$ versus the stress change during P91 steady-state creep

Figure 7 presents instantaneous-elongation and contraction examples upon low changes in the stress of the P91 steels. In the figure, the $\Delta \varepsilon^{-}$was the instantaneous strain under a stress decrease and the $\Delta \varepsilon^{+}$was the instantaneous strain under a stress increase.

The relationship between the stress increment $|\Delta \sigma|$ and the instantaneous strain $|\Delta E|$ is presented in Figure 7. The creep demonstrates a viscous behavior because the absolute values of the instantaneous strain for the load increase were equal to the values for the load decrease.

Two types of creep at low stress exist. One is creep controlled by the diffusion including the lattice diffusion creep (Nabarro-Herring type ${ }^{22}$ at a high-T and grain boundary diffusion creep (Coble type) ${ }^{22}$ at an intermediate-T. The other is creep associated with dislocation movement including free flight motion (climb controlled) and viscous motion (glide controlled) ${ }^{23}$. When creep is controlled by the diffusion, the creep should be a non-viscous behavior. In this case, the absolute values of the instantaneous strain for a small-load increase should be apparently larger than the values for a small-load

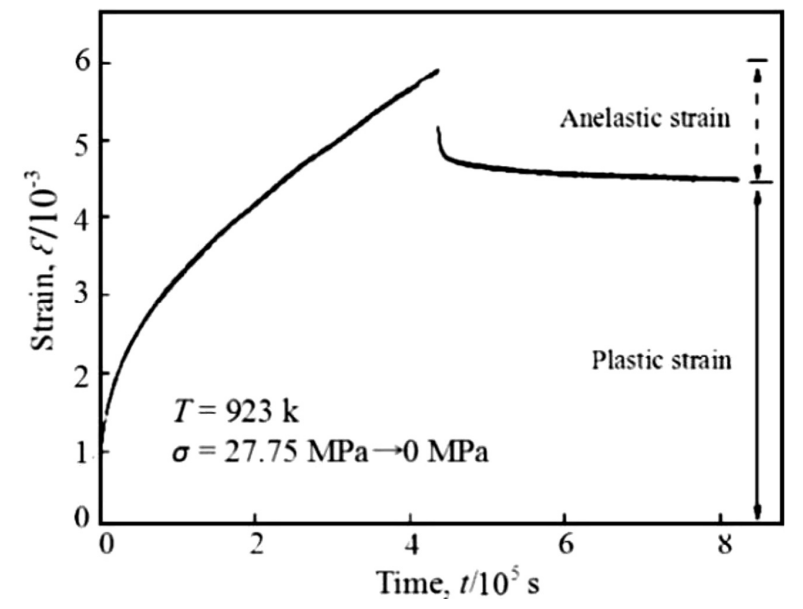

Figure 8: Elongation versus time during a high stress reduction without an elastic strain decrease. If creep is controlled by free flight motion of dislocation, plastic strain can occur instantaneously when the stress is increased by a small amount. Therefore, creep shows non-viscous behavior. When creep is controlled by the viscous glide of dislocations, instantaneous plastic strain does not occur even if the applied stress is increase suddenly. Thus, creep shows viscous behavior. In this study, the creep demonstrates a viscous behavior, because non instantaneous strain is observed during the stress increase. It means creep may be controlled by the viscous glide of dislocations.

Figure 8 gives an example of the anelastic backflow, observed for a high reduction in the stress during the transient-creep stage. Specifically, the helicoidal spring specimen was loaded at $27.75 \mathrm{MPa}$ and $923 \mathrm{~K}$ for $120 \mathrm{~h}$ and consequently unloaded all the stress for $120 \mathrm{~h}$. Two different parts of the creep strain existed: the anelastic strain was reversible, which is presented with solid double arrows, whereas the plastic strain was irreversible and it is presented with dashed double arrows. Therefore, the instantaneous strain that occurred under a sudden stress change included both elastic and anelastic components.

\section{CONCLUSIONS}

The short-term creep behavior in the P91 heat-resistant steels was investigated using instantaneous-stresschange tests. The results were as follows:

1) The creep deformation consisted of the primary creep stages, but no secondary creep stage was observed.

2) The Blackburn equation could be utilized for the creep-curve description because it provided an improved representation of the experimental creep curve.

3) The viscous glide of dislocations might have been the dominant creep mechanism because the creep displayed a viscous behavior.

4) The short-term creep at a low stress displayed an anelastic behavior.

\section{Acknowledgment}

This project was supported by the National Natural Science Foundation of China (Grant No. 51605330).

\section{REFERENCES}

${ }^{1}$ K. Kimura, Y. Takahashi, ASME 2012 Pressure Vessels \& Piping Division Conference, American Society of Mechanical Engineers, 18 (2012) 2, 177, doi:10.1016/0308-0161(93)90110-f

${ }^{2}$ K. Maruyama, J. S. Lee, Creep \& Fracture in High Temperature Components: Design \& Life Assessment Issues, DEStech

${ }^{3}$ H. G. Armaki, R. Chen, K. Maruyama, M. Igaras, Premature creep failure in strength enhanced high $\mathrm{Cr}$ ferritic steels caused by static recovery of tempered martensite lath structures, Materials Science and Engineering A, 527 (2010) 24-25, 6581-6588, doi:10.1016/ j. Msea. 2010. 07. 037 


\section{MATERIALI IN TEHNOLOGIJE/MATERIALS AND TECHNOLOGY (1967-2017) - 50 LET/50 YEARS}

\section{J. ZHE et al.: SHORT-TERM CREEP OF P91 HEAT-RESISTANT STEELS AT LOW STRESSES ...}

${ }^{4}$ O. Prat, J. Garcia, D. Rojas, G. Sauthoff, G. Inden, The role of Laves phase on microstructure evolution and creep strength of novel $9 \% \mathrm{Cr}$ heat resistant steels, Intermetallics, 32 (2013) 32, 362-372, doi:10.1016/j.internet.2012.08.016

${ }^{5}$ L. Kyu-Ho, H. Sung-Min, S. Jae-Hyeok, S. Jin-Yoo, H. Joo-Youl, J. Woo-Sang, Effect of $\mathrm{Nb}$ addition on Z-phase formation and creep strength in high-Cr martensitic heat-resistant steels, Materials Characterization, 102 (2015) 2, 79-84, doi:10.1016/j.Matchar. 2014. 12. 028

${ }^{6}$ X. Dong, Q. Z. Gao, C. Li, 9Cr-1.7W-0.4Mo-Co Ferritic Heat-Resistant Steel Isothermal Aging Microstructural Evolution, Publications, Lancaster, 85 (2008) 1-2, 372-379, doi:10.1016/j.ijpvp. 2007. 06. 006

${ }^{7}$ Transactions of Materials and Heat Treatment, 36 (2015) 3, 81-86, doi:10. 1016/j.Msea.2013.09.033

${ }^{8}$ K. Kimura, H. Kushima, K. Sawada, Long-term creep deformation property of modified $9 \mathrm{Cr}-1 \mathrm{Mo}$ steel, Materials Science and Engineering A, 511 (2009) 18, 58-63, doi:10.1016/j.msea.2008.04.095

${ }^{9}$ K. Kimura, Y. Toda, H. Kushima, K. Sawada, Creep strength of high chromium steel with ferrite matrix, International Journal of Pressure Vessels and Piping, 87 (2010) 6, 282-288, doi:10.1016/j.ij2010.03. 016

${ }^{10}$ E. M. Haney, F. Dalle, M. Sauzay, L. Vincent, I. Tournié, L. Allais, B. Fournier, Macroscopic results of long-term creep on a modified 9Cr-1Mo steel (T91), Materials Science and Engineering A, 510 (2009) 18, 99-103, doi: 10.1016/ j.msea. 2008. 04.099

${ }^{11}$ K. Maruyama, S. Karashima, Theoretical Consideration of Measurement of Work-Hardening and Recovery Rates during High Temperature Creep, Trans. Japan Inst. Metals, 16 (1975) 11, 671-678, doi:10.2320/matertrans1960.16.671

${ }^{12}$ K. Abe, H. Yoshinaga, S. Morozumi, A Method of Discerning Frictional Stress and Internal Stress by the Stress Relaxation Test, Journal of the Japan Institute of Metals and Materials, 18 (1997) 6, 479-487, doi:10.2320/matertrans 1960.18.479

${ }^{13}$ H. Oikawa, H. Sugawara, Instantaneous plastic strain associated with stress increments during the steady state creep of Al and Al - 5.5 At.
Pct. Mg alloy, Scripta Metall., 12 (1978) 1, 85-89, doi:10.1016/ 0036-9748(78)90234-x

${ }^{14}$ A. Magnin, Measurement of Very Low Creep Strains, Journal of Testing and Evaluation, 37 (2009) 1, 53-58, doi:10.1122/1.5550242

${ }^{15}$ J. J. Shen, K. Ikeda, S. Hata , H. Nakashima, Instantaneous creep in face-centered cubic metals at ultra-low strain rates by a highresolution strain measurement, Journal of Wuhan University of Technology (Materials Science Edition), 28 (2013) 6, 1096-1100, doi:10.1007/s11595-013-0826-y

${ }^{16} \mathrm{~S}$. Timoshenko, D. H. Yong, Elements of Strength of Materials, 5th ed., New York, Van Nostrand, 1968, 77-80

${ }^{17}$ A. M. Wahi, Mechanical Springs, 2nd ed., New York, McGraw Hill, 1963, 229-230

${ }^{18}$ M. R. Mitchel, R. E. Link, P. Marecek, Measurement of Very Low Creep Strain, A Review, J. Test. Eval., 37 (2009) 1, 53-58, doi:10. 15 20/jte 101475

${ }^{19}$ P. S. Zhang, J. J. Shen, H. Zhang, Short-Term Creep Behavior in P91 Heat-Resistant Steel at Low Stress, J. Material Science Forum, 850 (2016) 1, 922-926, doi:10.4028/www. scientific. net/ MSF.850.922

${ }^{20} \mathrm{~S}$. Holdsworth, Developments in the assessment of creep strain and ductility data, Materials at High Temperatures, 21 (2004) 1, 25-32, doi:10.3184/096034004782750041

${ }^{21}$ R. P. Reed, N. J. Simon , R. P. Walsh, Creep of copper: 4-300 K, Materials Science and Engineering A, 147 (1991) 1, 23-32, doi:10.1016/0921-5093(91)90801-s

${ }^{22}$ W. D. Nix, Effects of Grain Shape on Nabarro-Herring and Coble Creep Processes, Metals Forum, 4 (1981) 1, 38-43

${ }^{23}$ H. Hiroyuki, N. Satoshi, K. Junichi, K. Akihiro, Creep deformation characterization of heat resistant steel by stress change test, International Journal of Pressure Vessels and Piping, 24 (2009) 9, 556-562, doi:10.1016/j.ijpvp.2008.06.003

${ }^{24}$ K. Maruyama, S. Karashima, Theorethical Consideration of Measurement of Wor-Hardening and Recovery Rates during high temperature Creep, Trans. Japan Inst. Metals, 16 (1975) 11, 671-678, doi:10.2320/matertrans 1960.16.671 